\title{
Provasopressin expression by breast cancer cells: implications for growth and novel treatment strategies
}

\author{
Brendan P. Keegan ${ }^{1}$, Bonnie L. Akerman ${ }^{1}$, Christel Péqueux ${ }^{2}$ and William G. North ${ }^{1}$ \\ ${ }^{I}$ Department of Physiology, Dartmouth Medical School, Lebanon, NH, USA; ${ }^{2}$ Institute of Pathology CHU-B23, Center of Immunology \& \\ Laboratory of Neuroendocrinology, University of Liège, Liège 1-Sart Tilman, Belgium
}

\begin{abstract}
Summary
The arginine vasopressin (AVP) gene is expressed in certain cancers such as breast cancer, where it is believed to act as an autocrine growth factor. However, little is known about the regulation of the AVP protein precursor (proAVP) or AVP-mediated signaling in breast cancer and this study was undertaken to address some of the basic issues. The cultured cell lines examined (Mcf7, Skbr3, BT474, ZR75, Mcf10a) and human breast cancer tissue extract were found to express proAVP mRNA. Western analysis revealed multiple forms of proAVP protein were present in cell lysates, corresponding to those detected in human hypothalamus extracts. Monoclonal antibodies directed against different regions of proAVP bound to intact live Mcf7 and Skbr3 cells. Dexamethasone increased the amount of proAVP-associated glycopeptide (VAG) secreted by Skbr3 cells and a combination of dexamethasone, IBMX and 8br-cAMP increased cellular levels of VAG. Exogenous AVP (1, 10, and $100 \mathrm{nM}$ ) elevated phospho-ERK1/2 levels, and increased cell proliferation was observed in the presence of $10 \mathrm{nM}$ AVP. Concurrent treatment with the V1a receptor antagonist SR49059 reduced the effects of AVP on proliferation in Mcf7 cells, and abolished it in Skbr3 cells. Results here show that proAVP components are found at the surface of Skbr3 and Mcf7 cells and are also secreted from these cells. In addition, they show that AVP promotes cancer cell growth, apparently through a Vl-type receptor-mediated pathway and subsequent ERK1/2 activation. Thus, strategies for targeting proAVP should be examined for their effectiveness in diagnosing and treating breast cancer.
\end{abstract}

Keywords : arginine vasopressin (AVP); pro-arginine vasopressin (proAVP) ; vasopressin-associated glycopeptide (VAG) ; monoclonal antibody (mAb) ; extracellular signal-regulated kinase (ERK) ; neurophysinrelated surface antigen $(\mathrm{NRSA})$

\section{INTRODUCTION}

The neuropeptide arginine vasopressin (AVP) is generated in and secreted by hypothalamic neurons. The preprovasopressin precursor protein is $\sim 17 \mathrm{kDa}$, and after an $\mathrm{N}$-glycosidic side-chain of $\sim 4 \mathrm{kDa}$ is added, the resulting $\sim 20 \mathrm{kDa}$ provasopressin (proAVP) product is packaged into secretory vesicles. It undergoes enzymatic modification to generate AVP, vasopressin-associated neurophysin (VP-NP), and vasopressin-associated glycopeptide (VAG) [1]. Three G-protein coupled receptors (V1a, V1b, and V2) mediate the biological influence of AVP [2,3]. Additionally, the vasopressin-activated calcium mobilizing (VACM) protein has been described as a putative AVP receptor, although very little is known about its role in cell function [4]. Generally, signaling through the V1 receptors can involve the activation of phospholipase A2, C, D, and protein kinase C, leading to an increase in intracellular free $\mathrm{Ca}^{2+}$, and the activation of the mitogen-activated protein kinase (MAPK) and focal adhesion kinase (FAK). Signaling through the V2 receptor involves the activation of adenylate cyclase, protein kinase A, and a rise in intracellular CAMP. AVP aids in the regulation of blood pressure through the V1a receptor pathway, in the regulation of the adrenal-stress axis through the V1b receptor pathway, and acts as an antidiuretic through the V2 receptor pathway [2]. The biological functions of AVP are well denned, but those of VP-NP and VAG are not as well characterized. It is clear the VP-NP is important in the proper intracellular transport and processing of proAVP [5-7]. There are eight disulfide bridges within the 93 amino acids of the human VP-NP structure of proAVP, and further structural complexity is added through oligomerization. The processing of proAVP is dependent not only on protein sequence, but also on this oligomerization [5-7]. Although VAG is conserved among most mammals, its precise function remains elusive. One study indicates 
that it is important for the proper folding of proAVP [8], however another study suggests that it is not essential for proper proAVP processing [9].

The AVP gene is expressed in neuroendocrine tumors, while there is a low incidence of expression in the nonneuroendocrine tumor types examined [10]. AVP receptor signaling can initiate both mitogenic and antiproliferative effects on tumors and cultured tumor cells [11-15]. It has been suggested that the mitogenic effects of AVP are mediated through the V1 receptor, while the anti-proliferative effects are mediated through the V2 receptor [16-19]. The majority of research on AVP production and signaling in cancer has focused on small cell lung cancer (SCLC), such as the impact of glucocorticoids on AVP expression [20,21], promoter elements and transcription factors involved in AVP expression [22-27], detection of proAVP protein forms expressed [28,29], immunohistochemical screening of human tissues for proAVP protein products $[10,30,31]$, and intracellular mechanisms of AVP-stimulated proliferation [19]. Few such studies have been performed on other cancers that express neuropeptides, such as breast cancer. Breast cancer cells express all known AVP receptors [16], which can mediate AVP-induced growth in these cells [11]. In separate studies, we demonstrated that AVP appears to be expressed by all breast cancers, but not by the majority of normal tissues [30,31]. The current study shows that the proAVP message is present in all of the 5 cultured cell lines examined. Western analysis of cultured breast cancer cell lysates revealed multiple forms of proAVP protein, similar to what has been reported in cultured SCLC cells. Additionally, antibodies directed against the VP-NP or the VAG region of proAVP protein bind to live intact Mcf7 and Skbr3 cells. These cells are also able to secrete VAG, and in the case of the Skbr3 cells, VAG levels are increased in response to treatment with a cocktail of dexamethasone, 3-isobutyl-1methylxanthine, and 8-bromoadenosine 3',5'-cyclic monophosphate. Exogenous AVP can act to promote growth though the VI receptors by a process that appears to involve MAPK (ERK1/2) activation. Alternatively, activation of the V2 receptor in Mcf7 and Skbr3 cells by the specific agonist dDAVP resulted in a slight decrease in proliferation.

\section{METHODS}

\section{Cell culture and human tissue}

Cultured cell lines were maintained at $37{ }^{\circ} \mathrm{C}$ and $5 \% \mathrm{CO}_{2}$. The breast cell lines were obtained from the ATCC (Rockville, MD) and cultured in DMEM-F12 (Mediatech, Herndon, PA) with 10\% FBS (Hyclone, Logan, UT). The Lu-165 classical-type SCLC cell line, developed by Dr. T. Terasaki (Tokyo, Japan, [32]), was a gift from Dr. J. Coulson (Liverpool, UK), and was maintained in RPMI with 10\% FBS. Human breast tissue samples were obtained through the Cooperative Human Tissue Network (University of Alabama at Birmingham). Human hypothalamus tissue used for RNA extraction and PCR analysis was obtained at autopsy by Dr. C. Harker Rhodes (Dartmouth Medical School). Human hypothalamic paraventricular nucleus (PVN) and supraoptic nucleus (SON) tissues used for Western analysis were obtained at autopsy by Dr. Brent Harris (Dartmouth Medical School).

\section{Anti-pro AVP antibodies}

Antibody production and characterization have been described previously for the monoclonal antibody (mAb) against the VAG region, MAG1 [28], the mAb against the VP-NP region, NAB1 [10], and the polyclonal antibody against the VAG region [31].

\section{RT-PCR}

Reactions were performed using an Eppendorf Master-cycler Gradient thermocycler (Brinkmann, Westbury, NY). Total RNA was isolated from cultured cells or human tissues using TRIzol (Gibco BRL, Rockville, MD), and $1 \mu \mathrm{g}$ was used together with oligo-dT primers and RNase $\mathrm{H}$ reverse transcriptase (Invitrogen, Carlsbad, CA) following the manufacture's instructions. PCR amplification was performed using Eppendorf DNA Taq polymerase in a standard 30-cycle reaction. The proAVP message was amplified using the following primers, which are designed to amplify the entire coding sequence, and an annealing temperature of $56.4{ }^{\circ} \mathrm{C}$.

Forward: cttctcctcegcgtgcta Reverse: cgtccagctgc-gtggcgttgct

ReadyMade Primers (Integrated DNA Technologies, Skokie, IL) specific for Gapdh were used for control reactions, carried out using an annealing temperature of $54^{\circ} \mathrm{C}$. RT-PCR products were separated by agarose gel electrophoresis and visualized by ethidium bromide staining and an Alpha Innotech FluorChem 8900 (San Leandro, CA). 


\section{A VP-induced ERK1/2 activation and cell proliferation}

Skbr3 and Mcf7 cells were seeded onto plastic culture dishes or multi-well plates and allowed to adhere overnight. For assessment of ERK1/2 activation, the cells were serum-starved in RPMI without phenol red containing 1\% BSA and for $12 \mathrm{~h}$ prior to treatment with AVP. Cells were lysed (HEPES $20 \mathrm{mM}, \mathrm{NaCl} 150 \mathrm{mM}$, glycerol 10\%, Triton X-100 0.5\%, DTT $1 \mathrm{mM}, \mathrm{Na}_{3} \mathrm{VO}_{4} 1 \mathrm{mM}, \beta$-glycerophosphate $25 \mathrm{mM}, \mathrm{NaF} 1 \mathrm{mM}$, Complete $^{\mathrm{TM}} 1$ tablet $/ 50 \mathrm{ml}$ ) and subjected to Western analysis as described below. For assessment of cell proliferation, cells were cultured overnight in RPMI containing 5\% charcoal-stripped FCS prior to treatment. The media was then replaced with identical media containing 10\% alamarBlue (BioSource, Camarillo, CA). Dilutions of untreated cells were prepared and incubated in alamarBlue concurrently to generate a standard curve and ensure readings were measured in a linear range. Duration of treatments and concentrations of AVP, the AVP derivative and specific V2 agonist desmopressin (dDAVP), the V1a receptor antagonist SR49059, and the V2 receptor antagonist SR121463, are indicated in the text and figure legends. The receptor antagonists were a kind gift from Dr. C. Serradeil-Le Gal (Sanofi Recherche, France).

\section{ELISA and RIA for pro AVP}

Approximately $10^{4}$ cells were seeded onto 12 -well plates, cultured overnight, and then kept in serum-free conditions for $18 \mathrm{~h}$ prior to treatment. After which, they were treated with dexamethasone or a cocktail of dexamethasone, 3-Isobutyl-1-methylxanthine (IBMX), and 8-bromoadenosine 3',5'-cyclic monophosphate (8brcAMP). The final concentrations of treatment reagents were: $50 \mathrm{nM}$ dexamethasone, $0.5 \mathrm{mM}$ IBMX, and 0.5 mM 8br-cAMP. Treatment was carried out over 4 days with the media and treatment reagents changed on the second day. The media was then removed and replaced with PBS. After $1 \mathrm{~h}$ at $37^{\circ} \mathrm{C}$, the PBS was removed and used for RIA. Cells were lysed in TBS with $0.1 \%$ Tween- 20 containing a cocktail of protease inhibitors (Roche). Protein concentrations were determined by BCA (Pierce), which indicated that total protein yields were similar regardless of treatment. A synthetic peptide representing the C-terminal 18 amino acids of the human VAG region (VAGc18) was conjugated to BSA using gluteraldehyde, and used to coat the wells of Microfluor 2 Black ELISA plates (Dynex Technologies, Chantilly VA). Additionally, some wells were coated with glutaraldehydetreated BSA to serve as a non-specific binding control. Plates were incubated in blocking buffer (TBS, $0.1 \%$ BSA, $0.05 \%$ Tween-20, $\left.0.01 \% \mathrm{NaN}_{3}, \mathrm{pH} 7.2\right)$ for $30 \mathrm{~min}$ at room temperature. Lysate $(50 \mu \mathrm{g})$ was reacted with MAGI (2 ng) or non-specific isotype control mAb (ICN Pharmaceuticals) in $100 \mu 1$ of PBS in the microtiter plate wells for $2 \mathrm{~h}$ at $37^{\circ} \mathrm{C}$. Plates were then incubated with biotinylated goat anti-mouse (Fab-specific, Sigma) for $1 \mathrm{~h}$, and alkaline phosphatase-conjugated streptavidin (Calbiochem) for $1 \mathrm{~h}$. Washes were performed in between each successive incubation using blocking buffer. A final wash was performed using substrate buffer $\left(0.05 \mathrm{M} \mathrm{Na}_{2} \mathrm{CO}_{3}, 0.05 \mathrm{mM} \mathrm{MgCl}\right)$, after which fluorogenic substrate ( $0.2 \mathrm{mM}$ 4-methylumbelliferyl phosphate) in substrate buffer was added to the wells and readings were taken using $365 \mathrm{~nm}$ excitation and $450 \mathrm{~nm}$ emission wavelengths on a Synergy HT plate reader (Bio-Tek Instruments). A standard curve was generated using dilutions of unconjugated VAGcl8 incubated with $2 \mathrm{ng}$ MAGI. RIA was performed to detect products secreted into the PBS media as described earlier for AVP [33] using the polyclonal antibody against the VAG region and ${ }^{125}$ I-labeled VAGc18.

\section{Immunofluorescence and cytometric analysis}

Binding of anti-proAVP mAbs to live intact cells was assessed by indirect immunofluorescent analysis. Cells were seeded onto glass coverslips and cultured overnight. Iced-cold PBS containing $0.1 \% \mathrm{BSA}$ and $0.01 \% \mathrm{NaN}_{3}$ was used for washes and antibody incubations. Cells were washed and incubated at room temperature for $1 \mathrm{~h}$ in buffer containing $40 \mu \mathrm{g} / \mathrm{ml}$ anti-proAVP mAbs or isotype-matched antibodies IgG1 (MopC21, MP Biomedicals, Aurora $\mathrm{OH}$ ) and UPC-10 (IgG2a, Sigma, St. Louis MO) as controls for MAGI and NAB1, respectively. After four washes, the cells were fixed using $0.5 \%$ paraformaldehyde in PBS for 20 min rinsed four times with PBS, and incubated at room temperature for $1 \mathrm{~h}$ in buffer containing a 1:50 dilution of fluorescein isothiocyanate (FITC)-conjugated goat anti-mouse IgG (ICN). Coverslips were mounted utilizing SlowFade Light (Molecular Probes, Eugene, OR), and fluorescence was recorded using a Micropublisher camera (Qimaging, Burnaby, British Columbia, Canada) connected to a BX51 microscope (Olympus, Melville, NY) with UPlanAPO and UPlanFL optics. Flow cytometry was performed on cells that had been removed from their culture flasks using CellStripper cell dissociation solution (Mediatech) and reacted with antibody as described above and the fluorescence was measured on a FACStar flow cytometer (Becton Dickinson, Mountain View CA). 


\section{Western analysis}

Cultured cell protein samples were separated on 12.5\% gels by SDS-PAGE (25 mM Tris, $192 \mathrm{mM}$ glycine, $0.1 \%$ SDS, $\mathrm{pH}$ 8.3), and then transferred onto Immobilon-P PVDF membrane (Millipore, Bedford, MA) in the Trisglycine buffer with 20\% methanol added, using the MiniProtean 3 system (BioRad, Hercules, CA). Membranes were blocked using 5\% non-fat dried milk in Tris-buffered saline with $0.1 \%$ Tween-20 (TBST), and proAVP was detected using the antibody indicated in the text at a dilution of $1 \mu \mathrm{g} / \mathrm{ml}$ for the $\mathrm{mAbs}$. After washing, a goat anti-mouse HRP-conjugated secondary antibody was employed (Santa Cruz Biotechnology, Santa Cruz CA) and detection was carried out using chemiluminescent substrate (Pierce, Rockford IL), and exposure to autoradiography film. If membranes were to be re-probed, antibodies were stripped from the membranes by incubation in $0.1 \mathrm{~N} \mathrm{NaOH}$ for 5 min at room temperature, washed in TBST, blocked, and subjected to incubation with a different primary antibody. Mouse monoclonal anti-Gapdh antibody (Chemicon International, Temecula CA) was used as an assay control. For the detection of phospho-ERK1/2, blots were blocked in PBS containing $0.5 \%$ Tween-20, and then incubated in the same buffer containing a $1 \mu \mathrm{g} / \mathrm{ml}$ dilution of anti-phosphop42/44 ${ }^{\mathrm{MAPK}}$ polyclonal antibody (Cell Signaling Technology, Beverly MA). The remainder of the procedure was that as described above using a goat anti-rabbit HRP-conjugated secondary antibody (ICN), and after stripping the membranes they were re-probed using anti-p42/44 ${ }^{\mathrm{MAPK}}$ (Cell Signaling Technology).

Figure 1. AVP is expressed in cultured breast cancer cells and breast cancer tissue extract, but not in normal breast tissue extract, (a) The expression of AVP in cultured breast cancer cell lines BT474, Mcf7, Skbr3, ZR75, and Mcf10 a was examined by RT-PCR using oligo-dT primers and proAVP primers designed to amplify the entire coding sequence of proAVP. (b) RNA was extracted from human breast cancer and normal breast tissue samples for identical analysis by RT-PCR. Control reactions are human hypothalamus RNA (hHT, positive) and reaction without template (No Tem, negative). Direct sequence analysis of the Mcf7 and Skbr3 PCR product using nested primers indicated normal proAVP message. Products were separated on a 1.5\% agarose gel, which was then stained with ethidium bromide. Only one band was detected and that correlated to the predicted size (365 bp) for the amplification product. Direct sequence analysis using nested primers indicates normal provasopressin message.

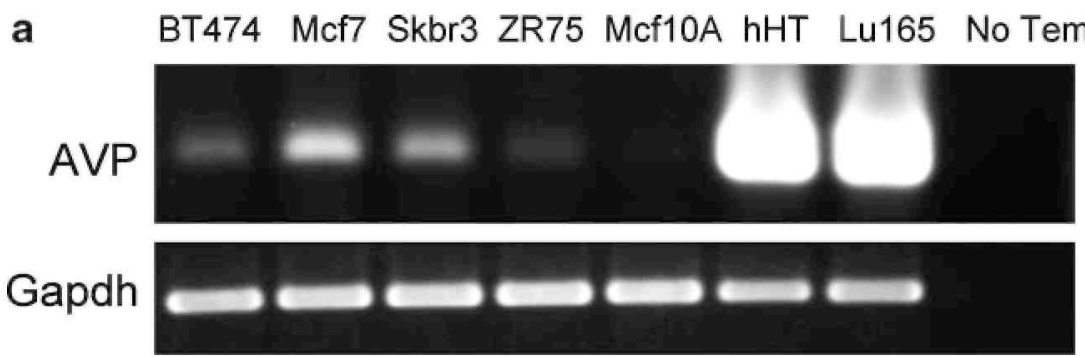

b

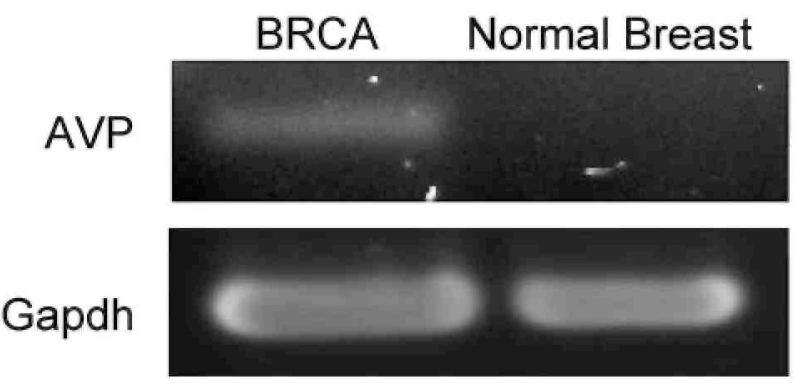

\section{RESULTS}

\section{Expression of pro AVP mRNA by cultured breast cancer cells and human breast cancer tissue}

Cell lines were chosen to represent various phenotypes of breast cancer: estrogen receptor $(\mathrm{ER} \alpha)$ positive (BT474, Mcf7, ZR75), mutant p53 (BT474, Skbr3), high ErbB2 expression (BT474, Skbr3). The Mcf10a cell line is derived from spontaneously immortalized cells of a fibrocystic disease specimen. RT-PCR analysis 
indicates that the proAVP message is present in each of the cell lines examined. Additionally, the proAVP message was detected in RNA extracted from human breast cancer tissue, but not in non-cancerous human breast tissue obtain from a breast reduction sample (Figure 1). RNA was extracted from human hypothalamus and Lu165 cells for use as positive controls. Skbr3 and Mcf7 cells were chosen for further analysis as representatives of ErbB2-positive ER $\alpha$ negative (Skbr3) and ErbB2-nega-tive ER $\alpha$ positive (Mcf7) breast cancer cells [34].

\section{Detection of proAVP protein forms by Western analysis}

Skbr3 and Mcf7 whole cell lysates, and extracts of human hypothalamic tissue were subjected to Western analysis utilizing MAG1 and NAB1 anti-pro AVP mAbs. In both cell lines, a doublet at 38/41 kDa and a band at $20 \mathrm{kDa}$ were detected using the proAVP antibodies (Figure 2). These results are similar to what we observed in SCLC cell lines and tissue extracts with MAG1 and in breast cancer tissue with NAB1 [28,31]. MAG1 also detected prominent bands at $38 \mathrm{kDa}$ and at $20 \mathrm{kDa}$ in human hypothalamic paraventricular nucleus (PVN) and supraoptic nucleus (SON) tissue extract, while NAB1 detected a single band at $38 \mathrm{kDa}$. The nature of these proAVP forms is not entirely known, however studies suggest that proAVP multimers exists as a product of VPNP region-dependant interactions that may be resistant to reduction $[5,6,35]$. It does appear that some antibodies generated against proAVP are not able to readily react with all of the individual molecular mass forms that have been identified [35].

\section{Immunofluorescent analysis using proAVP mAbs}

We have demonstrated that epitopes of proAVP are accessible to antibodies in live intact SCLC cells $[21,28,29,36,37]$. Similarly, proAVP was detected in live intact Skbr3 and Mcf7 cells by immunofluorescent analysis, utilizing mAbs against the VAG or VP-NP region (MAG1 or NAB1, respectively). Detection at the surface region of these cells (Figure $3 \mathrm{a}, \mathrm{c}, \mathrm{f}$ ) indicates the availability of the neurophysin-related surface antigen (NRSA) [28,29]. No reaction was observed with isotype control antibodies. Skbr3 cells are know to have a high level of ErbB2 at their surface, and the localization of staining observed using MAG1 and NAB1 appeared similar to that observed on Skbr3 cells using an anti-ErbB2 mAb (Figure 3e). To contrast the surface region localization, cells were fixed and permeabilized with methanol prior to reaction with anti-proAVP mAbs, revealing diffuse cytoplamic staining (Figure 3b, d).

Figure 2. proAVP forms are present in breast cancer cell lysates and human hypothalamic tissue extracts. Lysates and extracts were analyzed by SDS-PAGE using a 12.5\% gel and Western blot using MAG1 and NAB1 $m A b s$. Since proAVP is normally expressed by the hypothalamus, extracts from regions of the human hypothalamus (PVN: paraventricular nucleus, SON: supraoptic nucleus) were used for comparison with the breast cell lysates. Molecular mass markers $(k D a)$ are indicated on the left side of the figure.

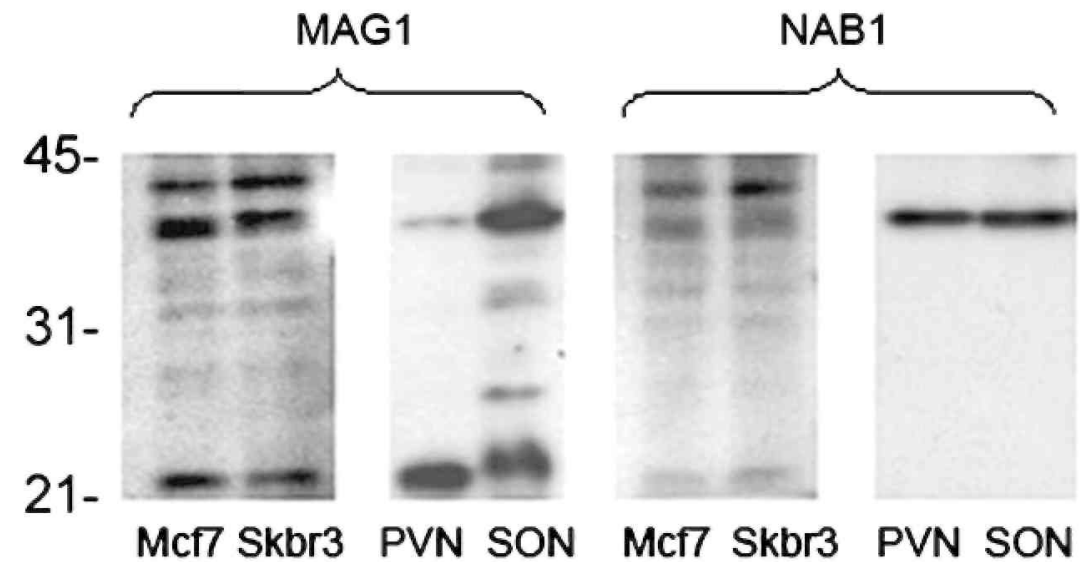

\section{proAVP VAG levels and secretion by Mcf7 and Skbr3 cells}

Glucocorticoids and cAMP-dependant signaling pathways can regulate AVP gene expression. Previous studies demonstrated that dexamethasone decreased the proAVP mRNA and VP-NP protein expression in SCLC cells, while a cocktail containing dexamethasone, IBMX and 8br-cAMP increased their expression [20,21]. Mcf7 and 
Skbr3 cells were subjected to similar treatments to examine the effect on intracellular and secreted proAVP levels. Cells were cultured in the presence of dexamethasone or a combination of dexamethasone, IBMX, and 8br-cAMP for 4 days. The cells were briefly washed and then incubated in PBS for $1 \mathrm{~h}$. The PBS was collected to measure secreted VAG by RIA, and the cells were lysed to measure cellular VAG by ELISA. Secreted VAG levels in the control samples were found to be similar in the Skbr3 and Mcf7 cells (Figure 4a). Dexamethasone treatment increased the amount of VAG secreted by the Skbr3 cells, but had no effect on the Mcf7 cells. The amount of secreted VAG detected in the media was not altered after treatment with the dexamethasone, IBMX, and 8br-cAMP cocktail over the course of the assay. Cellular VAG levels in control samples were also found to be similar in both cell lines (Figure 4b), and they remained unchanged after dexamethasone treatment. The amount of VAG detected in Skbr3 cell lysate was greater after treatment with the dexamethasone, IBMX, and 8br-cAMP combination, but remained unchanged in the Mcf7 cell lysate. Additionally, the binding of MAG1 to live intact Skbr3 and Mcf7 with or without prior treatment with a combination of dexamethasone, IBMX, and 8br-cAMP was analyzed by flow cytometry. Specific binding to both cell lines was observed (Figure 5a) and treatment with the cocktail was found to increase this binding in the Skbr3 cells, but not in the Mcf7 cells (Figure $5 b)$, supporting the findings obtained utilizing the ELISA assay (Figure 4).

\section{A VP-induced ERK1/2 activation and cell proliferation}

Recently, we demonstrated that AVP activated ERK1/2 in SCLC cells and increased their proliferation [19]. Similarly, AVP activated ERK1/2 in Mcf7 and Skbr3 breast cancer cells (Figure 6). Phospho-ERK1/2 levels were increased in Skbr3 and Mcf7 cells after they were incubated for 5 min with 1, 10, or $100 \mathrm{nM}$ AVP. After 15 min of continuous incubation with AVP, ERK1/2 activation persisted in the Mcf7 cells, but returned to basal levels in the Skbr3 cells. The experiment was performed twice with Skbr3 cells and three times with Mcf7 cells, yielding similar results. AVP has been shown to increase Mcf7 cell proliferation [11], therefore the proliferation of Mcf7 and Skbr3 cells in response to AVP was compared (Figure 7a). AVP at $1 \mathrm{nM}$ increased cell proliferation about $10 \%$, and AVP at $100 \mathrm{nM}$ increased cell proliferation about $20 \%$ (not shown). The differences in proliferation observed between $10 \mathrm{nM}$ and $100 \mathrm{nM}$ were not statistically significant, therefore a concentration of $10 \mathrm{nM}$ was chosen for subsequent experiments. AVP (10 nM) increased Mcf7 and Skbr3 cell proliferation by approximately $8 \%$ and $15 \%$ at day 1 , and by approximately $22 \%$ and $19 \%$ at day 3 , respectively. The increase observed at day 3 is comparable to what we observed for H345 and H146 SCLC cells [19]. We have shown that AVP-induced SCLC cell proliferation is mediated by the V1a receptor [19]. Therefore, the V1a receptor antagonist SR49059 was used to examine the impact of endogenous and exogenous AVP on breast cancer cell proliferation. When Mcf7 cells were incubated with both SR49059 (10 nM) and AVP (10 nM), the AVP-induced increase in proliferation at day 3 was reduced from $22 \%$ to $15 \%$ that of the untreated cells. When Skbr3 cells were incubated with both SR49059 and AVP, their proliferation was similar to untreated cells. Thus, it appeared the SR49059 reduced the exogenous AVP-induced growth in Mcf7 cells and abolished it in Skbr3 cells. When Mcf7 and Skbr3 cells were cultured in the presence of $10 \mathrm{nM} \mathrm{SR} 49059$ alone, they displayed similar growth as untreated control cells (not shown). The V2 agonist dDAVP appears to inhibit breast cancer cell metastasis [18,38], and the V2 receptor may mediate anti-proliferative effects [17]. Cells were exposed to $10 \mathrm{nM}$ dDAVP alone or in the presence of the V2 antagonist SR121463 and their proliferation was measured. dDAVP (10 nM), reduced proliferation in Mcf7 and Skbr3 cells to $92 \%$ and $93 \%$ that of controls at day 3, respectively (Figure $7 \mathrm{~b}$ ). Although the decrease in proliferation was not dramatic, it could be blocked by co-incubation with the selective V2R antagonist SR121463 in both cell lines, indicating the anti-mitogenic effect of dDAVP results from V2 receptor activation. As expected, SR121463 alone had no effect on the proliferation of either cell line (not shown). 
Figure 3. proAVP epitopes are present on breast cancer cells. MAG1 anti-VAG mAb or NAB1 anti-NP mAb were reacted with live intact and fixed permeabilized breast cancer cells for $1 \mathrm{~h}$. A secondary FITC-labeled goat anti-mouse antibody was used in each case with live cells fixed prior to this step. Live Skbr3 cells were reacted with ErbB2 antibody to illustrate the localization of immunoreactivity. Images required exposure times of 4 seconds for live cells, 2 seconds for fixed cells, and 0.5 seconds for Skbr3 cells reacted with anti-ErbB2 mAb at $40 \times$ magnification. Inset image is the reaction with isotype control antibody, (a) live intact Mcf 7 cells reacted with MAG1, (b) fixed permeabilized Mcf7 cells reacted with MAG1, (c) live intact Skbr3 cells reacted with MAG1, (d) fixed permeabilized Skbr3 cells reacted with MAG1, (e) live intact Skbr3 cells reacted with antiErbB2 $m A b$, and $(f)$ live intact Skbr3 cells reacted with $N A B 1$.
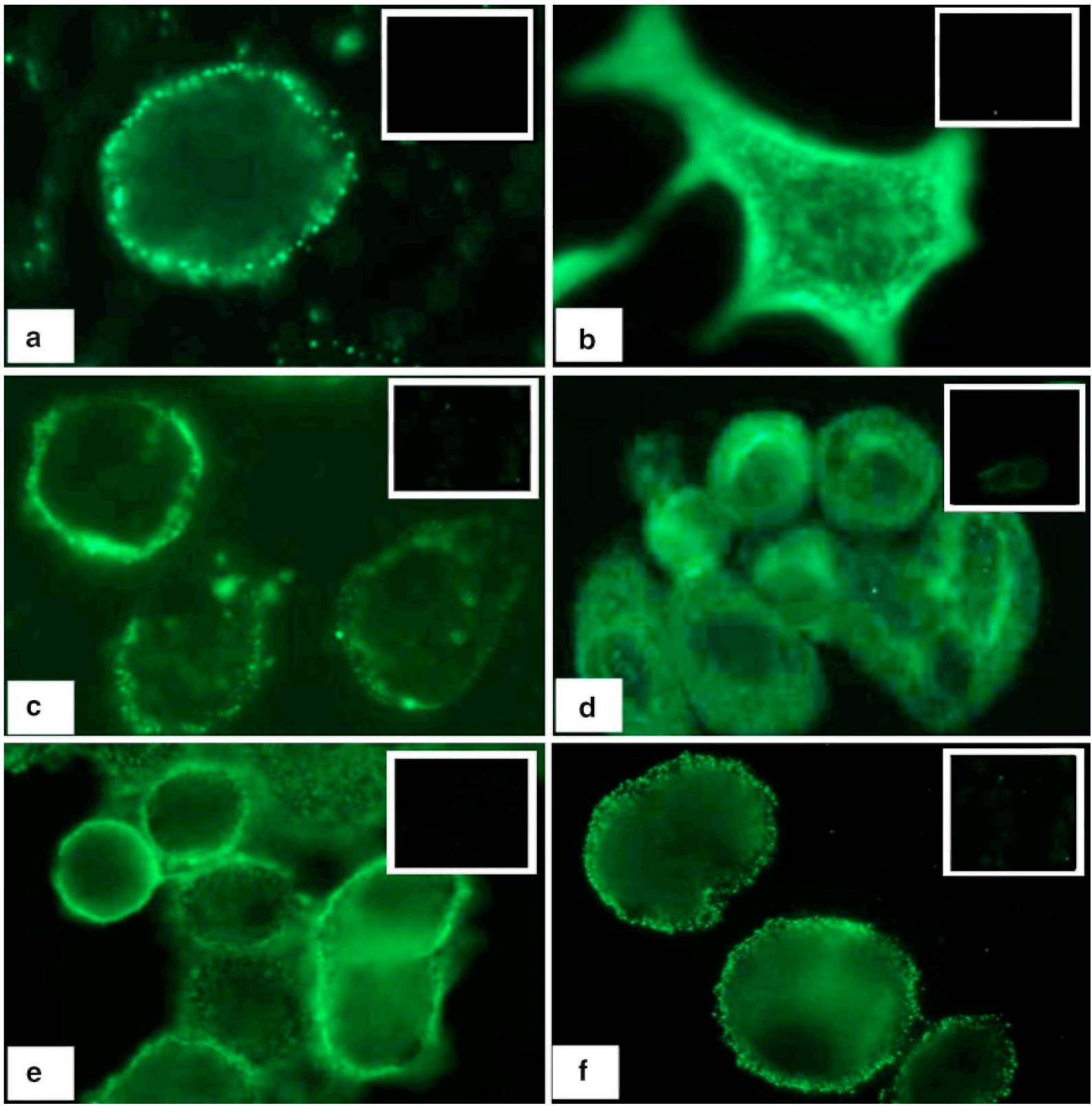
Figure 4. Dexamethasone (Dex) or a combination of dexamethasone, IBMX, and 8br-cAMP can regulate proAVP production and secretion in Skbr3 cells, (a) RIA was performed to measure secreted VAG using a polyclonal antibody directed against the VAG region of proAVP and iodinated-VAGcl8 peptide, and the amount of bound iodinated-VAGc18 peptide was compared to a standard curve, (b) ELISA was carried out to determine $V A G$ concentration in cell lysates using 96-well plates coated with VAGc18 peptide conjugated to BSA. MAG1 $(1 \mu \mathrm{g} / \mathrm{ml})$ was reacted with cell lysate $(50 \mu \mathrm{g})$ in the coated wells, or with dilutions of VAGcl8 to generate standard curves. Biotinylated goat anti-mouse and alkaline phosphatase-conjugated streptavidin were used to detect MAG1 bound in the wells. Fluorogenic substrate (0.2 mM 4-methylumbelliferyl phosphate) was used to generate signal and the relative fluorescence from each sample was compared to a standard curve to determine the concentration of VAG in those samples. The values plotted represent the mean obtained in each treatment group ( \pm SEM). Dark gray: Mcf7, Light gray, Skbr3. * t-test $p<0.05$ compared to controls.
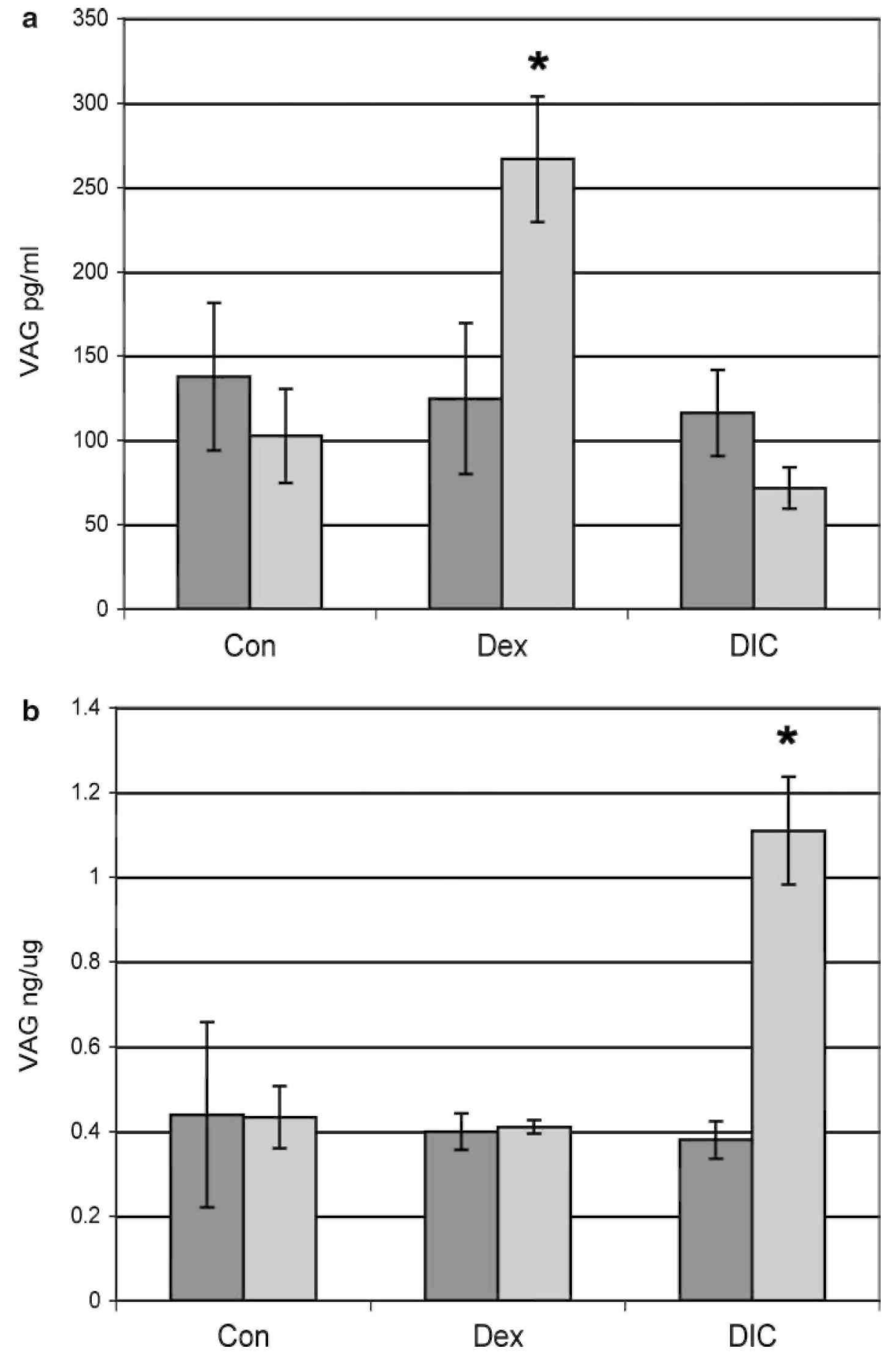


\section{DISCUSSION}

Little is known about the regulation of proAVP or AVP-mediated signaling in breast cancer, and the present study was designed to address some basic issues in this regard. We have demonstrated that proAVP mRNA is present in all 5 of the cultured cell lines examined, regardless of their reported levels of ER $\alpha$ expression, ErbB2 expression, p53 status, or tumor origin. Interestingly, we found proAVP mRNA in Mcf10a cells, which are derived from a spontaneously immortalized outgrowth of fibrocystic disease breast cells [39].

Immunohistochemical studies performed by us indicate that fibrocystic tissue specimens, not associated with malignant disease, do not contain proAVP protein products [30]. Although Mcf10A cells have been employed as cells from a non-cancerous origin, their expression profile of nuclear matrix proteins appears to be comparable to breast tissue that is between a normal and cancerous state [40]. It is possible then, that the expression of genes encoding neuropeptides and their receptors is a process associated with cellular immortalization. Recently, it was demonstrated that expression of the human V1a receptor in CHO cells resulted in a transformed phenotype that was associated with a loss of contact inhibited growth [41]. In apparent agreement with this notion, it was shown that activation of PI3K is essential for the transformation of human mammary epithelial cells in culture [42].

Western analysis with a mAb directed against the VAG region (MAG1) or the VP-NP region (NAB1) of proAVP revealed the presence of multiple proAVP forms in Mcf7 and Skbr3 cells. These results are similar to earlier reports that demonstrated proAVP forms of approximately 40, 30, and $20 \mathrm{kDa}$ in SCLC cell lines and tumor extracts [28,29,31]. Mcf7 and Skbr3 cells express a proAVP message that contains a normal sequence, therefore these forms should not be due to an abnormal prohormone. Additionally, we show that some of these forms are present in human hypothalamic extracts, although the $42 \mathrm{kDa}$ appears to be less prominent than in the tumor cell extracts. Other reports have identified higher molecular mass VP-NP-related species in extracts of bovine pituitary [35,43], rat and mouse hypothalamus [44-47], and human posterior pituitary [48]. The exact nature of the these forms has not been precisely determined, but the proAVP protein signal peptide is known to have an unusual sequence, which makes the processing of the protein inefficient and allows for its missorting even under normal circumstances [49]. Moreover, proAVP oligomerization may be an integral part of its processing and trafficking [5-7], and higher molecular mass forms of proAVP have been found to be resistant to reduction by various agents $[35,43,45-47]$. These forms and their stability may be a result of the 8 disulfide bridges within the 93 amino acids that comprise the VP-NP region of proAVP, and further structural complexity may be added as a result of oligomerization. This in turn may yield forms of proAVP that are not readily recognized by some antibodies that have been generated against certain regions of the proAVP sequence [35]. Hence, the slight difference in the proAVP forms detected using the MAG1 or the NAB1 mAbs in Western analysis is likely due to epitope availability. Anti-pro AVP antibodies are able to bind to the surface region of SCLC cells [21,28,29,36,37], and here we show that this appears to hold true for breast cancer cells as well. Indeed, MAG1 and NAB1 mAbs displayed a pattern of immunoreactivity on live cells that was similar to that observed using an anti-ErbB2 $\mathrm{mAb}$, and distinctly different from the diffuse staining observed in permeabilized cells. We have postulated that these epitopes are provided by unprocessed proAVP, and comprise what we have termed the neurophysin-related surface antigen (NRSA) [28,29]. 
Figure 5. Binding to live breast cancer cells measured by flow cytometry, (a) Breast cancer cells were removed from their culture vessels and reacted with MAG1 for $1 \mathrm{~h}$, washed, fixed in $0.5 \%$ paraformaldehyde, and reacted with FITC-labeled secondary antibody. The extent of binding was measured by flow cytometry and compared with unstained cells and cells reacted with MOPC21 isotype control antibody. White: Unstained; Grey: Isotype control; Black: MAG1, (b) The extent of binding was measured after cells were treated with a cocktail of dexamethasone, IBMX and 8br-cAMP (DIC). Cells were processed as in (a) after 4 days of treatment. The values represent the average mean values of the histograms obtained from each treatment group $( \pm S E M)$. * $t$ test $p<0.05$ compared to MOPC21 (isotype control) stained cells in the respective treatment group. Dark gray: Mcf7, Light gray: Skbr3.
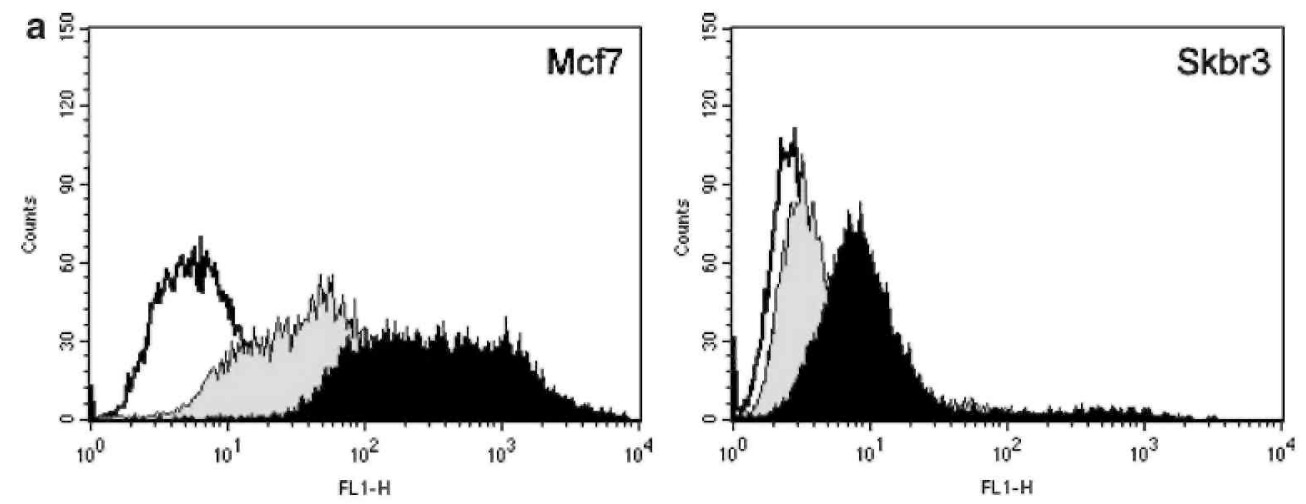

b

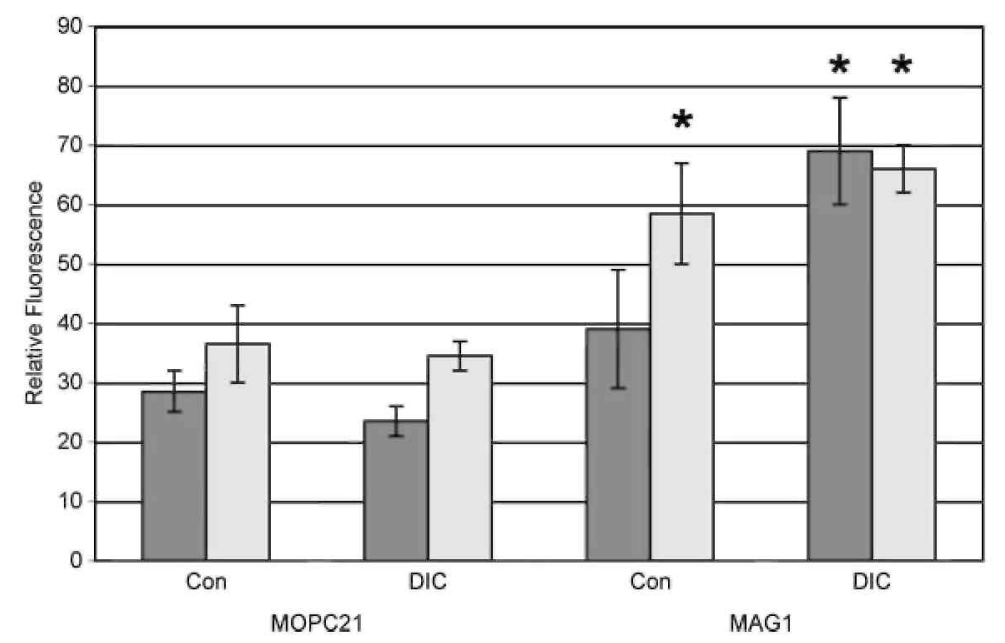

Figure 6. ERK1/2 is activated in breast cancer cells in response to exogenous AVP. Cells were cultured overnight in media containing 5\% charcoal-stripped FCS prior to AVP treatment. They were incubated continuously for 5 or 15 min in 1, 10, or $100 \mathrm{nMAVP}$ at $37^{\circ} \mathrm{C}$. Total cell lysates were prepared and subjected to Western analysis using anti-phospho-p42/44 ${ }^{M A P K}(P-E R K)$ and anti-p42/44 ${ }^{M A P K}$ (ERK) antibodies. This assay was repeated twice using the Skbr3 cell line and three times using the Mcf7 cell line with similar results.

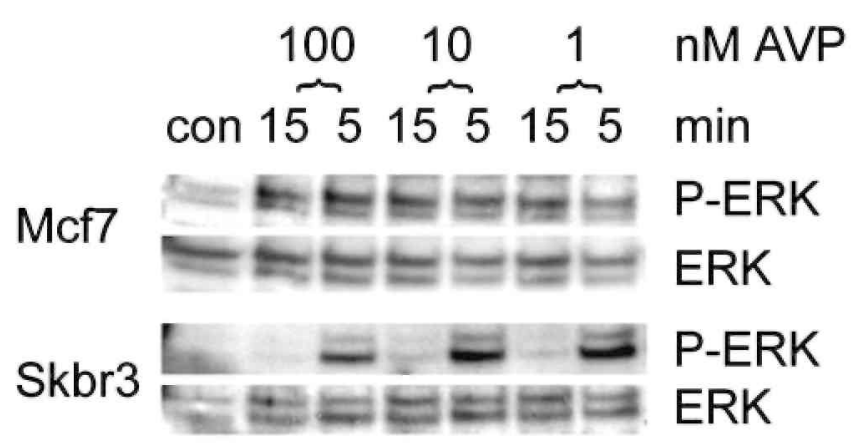


We are particularly interested in the use of the MAG1 mAb for detection of NRSA, in part because endogenously produced VAG has not been ascribed a biological function. External stimuli such as glucocorticoids are known to affect AVP gene transcription, and can regulate the amount of immunodetectable proAVP in SCLC cells [21]. Cellular and secreted VAG produced by Mcf7 and Skbr3 cells was measured, as was their response to dexamethasone or a combination of dexamethasone, IBMX, and 8br-cAMP.

Dexamethasone alone did not produce a measurable change in cellular VAG levels in either cell line, but it appeared to increase the amount secreted from Skbr3 cells. It is conceivable that the actions of dexamethasone on AVP gene transcription were not apparent because of the timeframe we considered. Additionally, factors such as differing levels of glucocorticoid receptor expression between the two cell lines may account for the selective effect of the steroid on AVP secretion from the Skbr3 cell line. We might have expected that the cocktail of dexamethasone, IBMX, and 8br-cAMP would increase the proAVP levels in Skbr3 cells and its secretion from them, but we found only the cellular levels to be increased. It would appear that the proAVP production and secretion pathways are not precisely coordinated in Skbr3 cells to effectively process and release AVP. The cocktail had no apparent effect on Mcf7 cells. The notion that alterations in the protein kinase A and C pathways are early and later events in breast cancer malignant transformation, respectively [50] may at least in part account for these differences. Rates of protein production, processing, or secretion were not determined, therefore these data do not indicate by which particular process such differences are manifested. However, dexamethasone has been shown to decrease, while the combination of dexamethasone, IBMX, and 8br-cAMP has been shown to increase the expression of AVP mRNA as well as AVP and VP-NP protein levels in cultured SCLC cells $[20,21]$. Additionally, 8br-cAMP was shown to increase the amount of AVP released from rat posterior pituitary expiants, but it had no effect on AVP mRNA content in the supraoptic nucleus [51]. A recent report indicates that proAVP protein levels are unchanged in human hypothalamus tissue sections from patients who received dexamethasone treatment, compared to those who did not, but the levels of mature AVP are decreased [52]. This effect could not be explained entirely by the down-regulation of processing enzymes. Thus, it appears that the regulation of AVP expression can be a very complex and cell-specific process [53]. These measurements were undertaken to determine if breast cancer cells display some of the regulatory aspects observed with SCLC cells with respect to proAVP expression. Although VAG was found to be secreted by the Mcf7 and Skbr3 cells, it was clear that there was cell-associated VAG that could be bound by MAG1. In the case of Skbr3 cells, treatment with a combination of dexamethasone, IBMX, and 8br-cAMP enhanced their immunoreactivity with MAG1 $\mathrm{mAb}$. These results are in agreement with earlier findings with H69 SCLC cells, and supported the notion that by inducing an increase in production of proAVP by tumor cells, immuno-based detection and treatment efforts may be enhanced [31]. 
Figure 7. AVP induces breast cancer cell proliferation and dDAVP inhibits proliferation. Incubations were carried out in 96-well plates for 1 and 3 days with continuous exposure to treatment. Proliferation was assessed using the AlamarBlue substrate and the values represent the average relative fluorescence obtained from the samples in each treatment group $( \pm S E M)$. (a) Both cell lines displayed an increase in proliferation when cultured in the presence of $10 \mathrm{nM}$ AVP compared to cells cultured in serum lacking AVP (Con). Closed circles: Control; Closed squares: AVP; Open squares: AVP and 10 nM SR49059. *t-test $p \leq 0.05$ compared to controls, $* * t$-test $p<0.05$ compared to controls and to AVP + SR49059. (b) Both cell lines display reduced proliferation in the presence of $10 \mathrm{nM} d D A V P$. Closed circles: Control; Closed squares: dDAVP; Open squares: dDAVP and $10 n M$ SR 121463. *t-test $p \leq 0.05$ compared to controls, **t-test $p \leq 0.05$ compared to controls and to dDAVP+ SR121463.
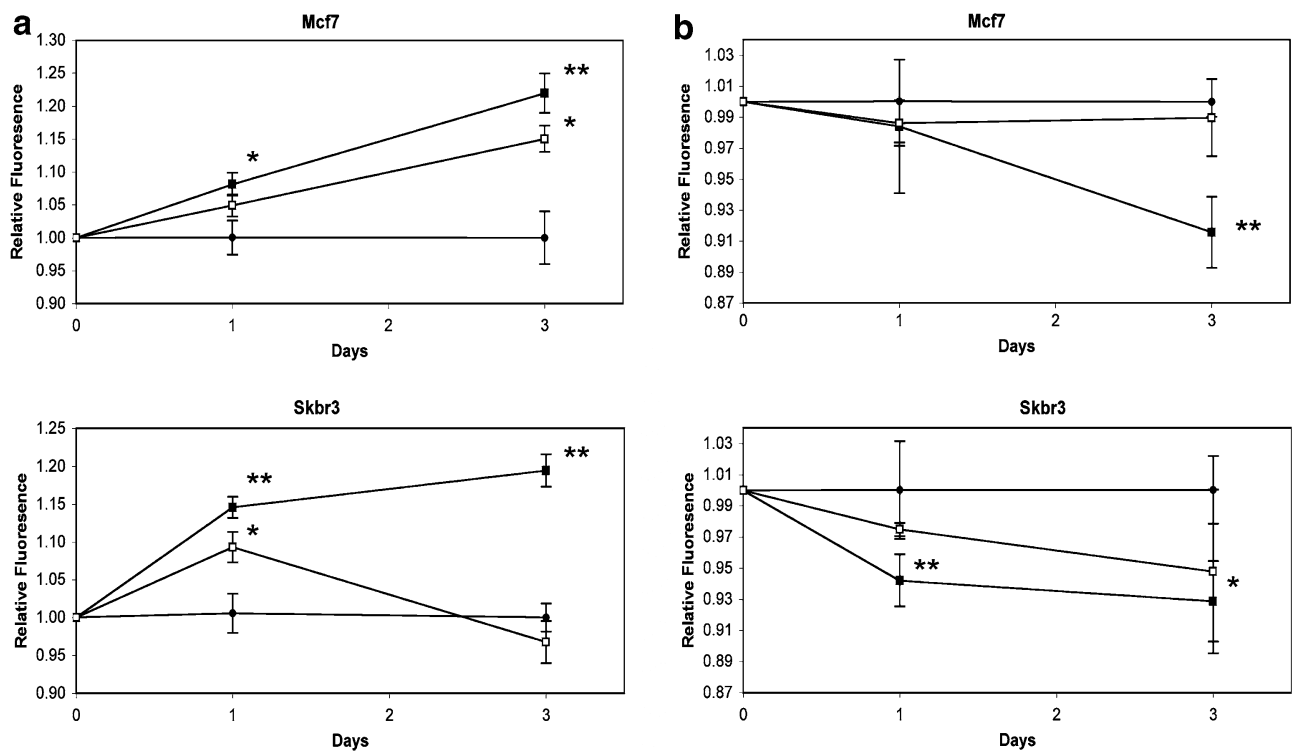

It is believed that neuropeptides and their receptors can form an autocrine/paracine growth loop in certain tumor cells. There are cases in the literature that describe the syndrome of inappropriate secretion of antidiuretic hormone (SIADH) in breast cancer patients [54-56], indicating that at least some breast cancer cells are capable of producing and secreting biologically active AVP. Mcf7 cells express the V1a, V1b and V2 AVP receptors [16], as well as the key enzymes required for the processing of the proAVP peptide [57]. We did find that the VAG region of proAVP was secreted by Mcf7 and Skbr3 cells, although we did not assess whether biologically active AVP was produced. However, exogenous AVP was found to activate ERK1/2 and increase the proliferation of these cells, which was comparable to what we observed with SCLC cells [19]. Activation of the V1a receptor has been shown to increase the levels of phosphorylated ERK1/2 and mediate the AVP-induced proliferation of SCLC cells, intestinal epithelial cells, and in V1a receptor-transfected cells [19,58-60]. Our results suggest that a similar growth promoting mechanism occurs in breast cancer cells in response to AVP. The transient AVP-induced ERK1/2 phosphorylation detected in the Skbr3 cell line is in agreement with data obtained on SCLC cells [19], but the ERK1/2 activation persisted longer in the Mcf7 cells. A recent report demonstrates a difference in the level and duration of ERK1/2 phosphorylation in Mcf7 cells in response to estradiol or IGF-1 [61]. Another study showed that ErbB2 overexpression in Mcf7 cells reduced IGF-1-induced ERK phosphorylation, and IGF-1-induced ERK phosphorylation was restored in Skbr3 cells overexpressing the IGF-1 receptor during antisense-mediated ErbB2 downregulation [62]. Additionally, estrogen-induced ERK1/2 activation in Mcf7 cells was shown to be dependant on the membrane ER $\alpha$ levels [63]. Thus, while the precise mechanisms responsible for the variation we observed between the two cell lines remain to be defined, the expression levels of membrane receptors, such as ErbB2 and membrane ER $\alpha$, and their affected downstream pathways could account for the differences observed in AVP-induced ERK1/2 activation. 
Taylor et al. showed that AVP had mitogenic effects at 10,100 and 1,000 pM on Mcf7 cells, but an inhibitory effect at $10 \mathrm{nM}$, that was attributed to a desensitization effect [11]. In apparent contrast to that study, we show here that $10 \mathrm{nM}$ AVP had a mitogenic effect on Mcf7 cells as well as Skbr3 cells. However, our experimental conditions differed from theirs in that their cells were cultured in media containing $2.5 \%$ fetal calf serum for three days prior to exposure to AVP, while our cells were cultured in media containing $5 \%$ charcoal-stripped serum overnight prior to exposure to AVP. Our conditions were chosen to replicate those of our recent work with SCLC cells, and the increased proliferation in the Mcf7 and Skbr3 cells was comparable to what we observed with H345 and H146 SCLC cells [19]. We did not find a decrease in Mcf7 or Skbr3 cell proliferation when they were cultured in the presence of the V1a receptor antagonist SR49059 alone. It would appear that other growthpromoting pathways, to include V1b receptor-mediated signaling [64], may compensate for the loss of AVPmediated V1a signaling under the conditions used for this study, and/or the time-course and exposure to SR49059 was not sufficient to observe cytostatic effects [65]. When SR49059 was included in the culture media in combination with AVP, Mcf7 cell proliferation was partially blocked, but Skbr3 cell proliferation was totally blocked. This may be a result of the persistent ERK1/2 activation observed in Mcf7 cells after AVP exposure, the ability of Mcf7 to produce endogenous AVP, and/or indicate that a V1b receptor mechanism may contribute to Mcf7 cell proliferation. Additionally, it has been postulated that signaling mediated by the V2 receptor may have an antiproliferative effect on SCLC cells [16,17]. Taylor et al. demonstrated that the V2-specific agonist dDAVP did not inhibit AVP binding to Mcf7 cells [11], although later work has shown that these cells do express the V2 receptor [16]. dDAVP can have an anti-metastatic effect on breast cancer cells in mouse tumor models $[18,38]$, however those studies indicate that dDAVP did not have a cytotoxic effect on the tumor cells. Additionally, human V1a receptor expressing $\mathrm{CHO}$ cells displayed increased thymidine uptake in response to AVP, while human V2 receptor expressing $\mathrm{CHO}$ cells displayed a reduction of thymidine uptake [60]. The affinity of AVP for the V1 receptors is approximately $1 \mathrm{nM}$ and it is just over $3 \mathrm{nM}$ for the V2 receptor. Therefore, we expect that at the levels of AVP used in this study we would be activating both V1 and V2 receptors. When the effect of AVP was blocked by SR49059, we did not observe a concomitant inhibition in cell proliferation as a result of V2 pathway stimulation. However we do show that dDAVP at a concentration of 10 $\mathrm{nM}$ had a small but statistically significant effect on reducing the proliferation of both Mcf7 and Skbr3 cells, and that this effect was abolished when the cells were incubated with both dDAVP and SR121462. Thus, in reported situations where AVP elicits any anti-proliferative effect, this effect is likely to be mediated through V2 receptor signaling. While this demonstrates that the V2 receptor can mediate an anti-proliferative pathway in these cells, the number of functional V2 receptors on these cells may be low. The effect of AVP on the proliferation of tumor or cultured cells should therefore be affected by receptor expression, functionality, and ligand concentration. Further work will more precisely define AVP-mediated growth mechanisms.

We have recently demonstrated that proAVP protein products can be detected in all human breast cancer tissues examined by IHC analysis, but not in normal breast tissue or fibrocystic tissue that is not associated with malignant breast disease, nor in 65 other various normal human tissues [30]. Together with this study, it appears that most if not all breast cancer cells express the AVP gene. Results here are similar to what is observed with SCLC cells in that proAVP can be targeted at the surface of breast cancer cells by mAbs. Additionally, proAVP protein components can also be secreted and AVP can promote breast cancer cell growth, apparently through VItype receptors and in an ERK1/2-dependant fashion. Altogether, these results suggest that novel strategies based on proAVP expression could be developed for the successful detection and treatment of breast cancer.

\section{ACKNOWLEDGMENTS}

We would like to thank C. Harker Rhodes and Brent Harris for obtaining the human hypothalamus tissues used in this study. Additionally, we would like to thank Jack Bodwell, Nicholas Johnston, and Raymond Perez for technical advice and reagents. This work was supported by grants to William G. North (PHS CA 92506 and DK 07508), though an NCI core grant to the Norris Cotton Cancer Center (CA 23108), and by a DOD fellowship to Brendan P. Keegan (DAMD 17-02-1-0365). Cytometric analysis was performed at the Herbert C. Englert Cell Analysis Laboratory, which was established by equipment grants from the Fannie E. Rippel Foundation, the NIH Shared Instrument Program, and Dartmouth Medical School.

\section{References}

1. North WG, Valtin H, Cheng S, Hardy GR: The neurophysins: production and turnover. Prog Brain Res 60: 217-225, 1983

2. Birnbaumer M: Vasopressin receptors. Trends Endocrinol Metab 11: 406-410, 2000

3. North WG, Fay MJ, Du J: All three vasopressin receptor subtypes are expressed by small-cell carcinoma. Adv Exp Med Biol 449: 335- 
Published in : Breast Cancer Research and Treatment (2006), vol. 95, pp. 265-277.

Status : Postprint (Author's version)

338,1998

4. Van Dort C, Zhao P, Parmelee K, Capps B, Poel A, Listenberger L, Kossoris J, Wasilevich B, Murrey D, Clare P, Burnatowska-Hledin M: VACM-1, a cul-5 gene, inhibits cellular growth by a mechanism that involves MAPK and p53 signaling pathways. Am J Physiol Cell Physiol 285: C1386-1396, 2003

5. de Bree FM, Knight D, Howell L, Murphy D: Sorting of the vasopressin prohormone into the regulated secretory pathway. FEBS Lett 475: $175-180,2000$

6. de Bree FM: Trafficking of the vasopressin and oxytocin prohormone through the regulated secretory pathway. J Neuroendocrinol 12 : $589-594,2000$

7. de Bree FM, Van Der Kleij AA, Nijenhuis M, Zalm R, Murphy D, Burbach JP: The hormone domain of the vasopressin prohormone is required for the correct prohormone trafficking through the secretory pathway. J Neuroendocrinol 15: 1156-1163, 2003

8. Barat C, Simpson L, Breslow E: Properties of human vasopressin precursor constructs: inefficient monomer folding in the absence of copeptin as a potential contributor to diabetes insipidus. Biochemistry 43: 8191-8203, 2004

9. Iwasaki Y, Oiso Y, Saito H, Majzoub JA: Effects of various mutations in the neurophysin/glycopeptide portion of the vasopressin gene on vasopressin expression in vitro. Tohoku J Exp Med 191: 187-202, 2000

10. Friedmann AS, Memoli VA, North WG: Vasopressin and oxytocin production by non-neuroendocrine lung carcinomas: an apparent low incidence of gene expression. Cancer Lett 75: 79-85, 1993

11. Taylor AH, Ang VT, Jenkins JS, Silverlight JJ, Coombes RC, Luqmani YA: Interaction of vasopressin and oxytocin with human breast carcinoma cells. Cancer Res 50: 7882-7886, 1990

12. Nilsson H, Eriksson LC: Growth factor induced mitogenic effects and inositol phosphate responses in primary hepatocyte cultures from normal rat liver and rat liver nodules. Carcinogenesis 15: 1821-1826, 1994

13. Schwindt TT, Forti FL, Juliano MA, Juliano L, Armelin HA: Arginine vasopressin inhibition of cyclin D1 gene expression blocks the cell cycle and cell proliferation in the mouse Y1 adrenocortical tumor cell line. Biochemistry 42: 2116-2121, 2003

14. Seck1 MJ, Higgins T, Widmer F, Rozengurt E: [D-Arg1,D-Trp5,7,9,Leu11]substance P: a novel potent inhibitor of signal transduction and growth in vitro and in vivo in small cell lung cancer cells. Cancer Res 57: 51-54, 1997

15. Yamaguchi T, Pelling JC, Ramaswamy NT, Eppler JW, Wallace DP, Nagao S, Rome LA, Sullivan LP, Grantham JJ: cAMP stimulates the in vitro proliferation of renal cyst epithelial cells by activating the extracellular signal-regulated kinase pathway. Kidney Int 57: 14601471,2000

16. North WG, Fay MJ, Du J: MCF-7 breast cancer cells express normal forms of all vasopressin receptors plus an abnormal V2R. Peptides 20: $837-842,1999$

17. North WG, Fay MJ, Longo KA, Du J: Expression of all known vasopressin receptor subtypes by small cell tumors implies a multifaceted role for this neuropeptide. Cancer Res 58: 1866-1871, 1998

18. Giron S, Tejera AM, Ripoll GV, Gomez DE, Alonso DF: Desmopressin inhibits lung and lymph node metastasis in a mouse mammary carcinoma model of surgical manipulation. J Surg Oncol 81: 38-44, 2002

19. Pequeux C, Keegan BP, Hagelstein MT, Geenen V, Legros JJ, North WG: Oxytocin- and vasopressin-induced growth of human smallcell lung cancer is mediated by the mitogen-activated protein kinase pathway. Endocr Relat Cancer 11: 871-885, 2004

20. Verbeeck MA, Sutanto W, Burbach JP: Regulation of vasopressin messenger RNA levels in the small cell lung carcinoma cell line GLC8: interactions between glucocorticoids and second messengers. Mol Endocrinol 5: 795-801, 1991

21. Friedmann AS, Fay MJ, Memoli VA, North WG: Factors regulating the production of vasopressin-associated human neurophysin by small-cell carcinoma of the lung: evaluation by computer-enhanced quantitative immunocytochemistry. Neuropeptides 28: 183-189, 1995

22. Coulson JM: Positive and negative regulators of the vasopressin gene promoter in small cell lung cancer. Prog Brain Res 139: 329-343, 2002

23. Coulson JM, Edgson JL, Marshall-Jones ZV, Mulgrew R, Quinn JP, Woll PJ: Upstream stimulatory factor activates the vasopressin promoter via multiple motifs, including a non-canonical E-box. Biochem J 369: 549-561, 2003

24. Coulson JM, Fiskerstrand CE, Woll PJ, Quinn JP: E-box motifs within the human vasopressin gene promoter contribute to a major enhancer in small-cell lung cancer. Biochem J 344 Pt 3: 961-970, 1999

25. Coulson JM, Fiskerstrand CE, Woll PJ, Quinn JP: Arginine vasopressin promoter regulation is mediated by a neuron-restrictive silencer element in small cell lung cancer. Cancer Res 59: 5123-5127, 1999 
26. Coulson JM, Stanley J, Woll PJ: Tumour-specific arginine vasopressin promoter activation in small-cell lung cancer. Br J Cancer 80 : $1935-1944,1999$

27. Coulson JM, Edgson JL, Woll PJ, Quinn JP: A splice variant of the neuron-restrictive silencer factor repressor is expressed in small cell lung cancer: a potential role in derepression of neuroendocrine genes and a useful clinical marker. Cancer Res 60: 1840-1844, 2000

28. Keegan BP, Memoli VA, North WG: Targeting the neurophysin-related cell surface antigen on small cell lung cancer cells using a monoclonal antibody against the glycopeptide region (MAG-1) of provasopressin. Mol Cancer Ther 1: 1153-1159, 2002

29. North WG, Yu XM: Vasopressin mRNA and neurophysin-related cell-surface antigen (NRSA) in small-cell carcinoma. Peptides 14: 303-307, 1993

30. North WG, Wells W, Fay MJ, Mathew RS, Donnelly EM, Memoli VA: Immunohistochemical evaluation of vasopressin expression in breast fibrocystic disease and ductal carcinoma in situ (DCIS). Endocr Pathol 14: 257-262, 2003

31. North WG, Pai S, Friedmann A, Yu X, Fay M, Memoli V: Vasopressin gene related products are markers of human breast cancer [published erratum appears in Breast Cancer Res Treat 1995;36(1):99]. Breast Cancer Res Treat 34: 229-235, 1995

32. Terasaki T, Matsuno Y, Shimosato Y, Yamaguchi K, Ichinose H, Nagatsu T, Kato K: Establishment of a human small cell lung cancer cell line producing a large amount of anti-diuretic hormone. Jpn J Cancer Res 85: 718-722, 1994

33. North WG, LaRochelle FT, Jr., Haldar J, Sawyer WH, Valtin H: Characterization of an antiserum used in a radioimmunoassay for arginine-vasopressin: implications for reference standards. Endocrinology 103: 1976-1984, 1978

34. Maggiolini M, Vivacqua A, Fasanella G, Recchia AG, Sisci D, Pezzi V, Montanaro D, Musti AM, Picard D, Ando S: The G proteincoupled receptor GPR30 mediates c-fos up-regulation by 17 beta-estradiol and phytoestrogens in breast cancer cells. J Biol Chem 279 : 27008-27016, 2004

35. Beguin P, Nicolas P, Boussetta H, Fahy C, Cohen P: Characterization of the 80,000 molecular weight form of neurophysin isolated from bovine neurohypophysis. J Biol Chem 256: 9289-9294, 1981

36. North WG, Maurer H, O'Donnell JF: The neurophysins and small cell lung cancer. In: Greco F. Martinus (ed.), Biology and Management of Lung Cancer. Nijhoff, Boston, 1983, pp. 143-169

37. North WG, Yu X: Forms of neurohypophysial peptides generated by tumors, and factors regulating their expression. Regul Pept 45: 209216,1993

38. Alonso DF, Skilton G, Farias EF, de Bal Kier Joffe E, Gomez DE: Antimetastatic effect of desmopressin in a mouse mammary tumor model. Breast Cancer Res Treat 57: 271-275, 1999

39. Soule HD, Maloney TM, Wolman SR, Peterson WD, Jr., Brenz R, McGrath CM, Russo J, Pauley RJ, Jones RF, Brooks SC: Isolation and characterization of a spontaneously immortalized human breast epithelial cell line, MCF-10. Cancer Res 50: 6075-6086, 1990

40. Khanuja PS, Lehr JE, Soule HD, Gehani SK, Noto AC, Choudhury S, Chen R, Pienta KJ: Nuclear matrix proteins in normal and breast cancer cells. Cancer Res 53: 3394-3398, 1993

41. Mackinnon AC, Tufail-Hanif U, Lucas CD, Jodrell D, Haslett C, Sethi T: Expression of V(1A) and GRP receptors leads to cellular transformation and increased sensitivity to substance-P analogue-induced growth inhibition. Br J Cancer 92: 522-531, 2005

42. Zhao JJ, Gjoerup OV, Subramanian RR, Cheng Y, Chen W, Roberts TM, Hahn WC: Human mammary epithelial cell transformation through the activation of phosphatidylinositol 3-kinase. Cancer Cell 3: 483-495, 2003

43. Nicolas P, Camier M, Lauber M, Masse MJ, Mohring J, Cohen P: Immunological identification of high molecular weight forms common to bovine neurophysin and vasopressin. Proc Natl Acad Sci USA 77: 2587-2591, 1980

44. Moore GJ, Rosenior JC: Characterization of the "giant precursors" (70-80 K) of vasopressin and oxytocin in the rat hypothalamus. Prog Brain Res 60: 253-256, 1983

45. Rosenior JC, North WG, Moore GJ: Biosynthesis of oxytocin and oxytocin-neurophysin in homozygous Brattleboro rats. Ann N Y Acad Sci 394: 183-187, 1982

46. Camier M, Lauber M, Mohring J, Cohen P: Evidence for higher molecular weight immunoreactive forms of vasopressin in the mouse hypothalamus. Relationships with putative proneurophysins. FEBS Lett 108: 369-373, 1979

47. Lauber M, Camier M, Cohen P: Immunological and biochemical characterization of distinct high molecular weight forms of neurophysin and somatostatin in mouse hypothalamus extracts. FEBS Lett 97: 343-347, 1979

48. Verbalis JG, Robinson AG: Characterization of neurophysin-vasopressin prohormones in human posterior pituitary tissue. J Clin Endocrinol Metab 57: 115-123, 1983 
49. Friberg MA, Spiess M, Rutishauser J: Degradation of wild-type vasopressin precursor and pathogenic mutants by the proteasome. J Biol Chem 279: 19441-19447, 2004

50. Starzec AB, Spanakis E, Nehme A, Salle V, Veber N, Mainguene C, Planchon P, Valette A, Prevost G, Israel L: Proliferative responses of epithelial cells to 8-bromo-cyclic AMP and to a Phorbol ester change during breast pathogenesis. J. Cell Physiol 161: 31-38, 1994

51. Song Z, Sidorowicz HE, Sladek CD: cAMP stimulation of vasopressin and oxytocin release and regulation of vasopressin niRNA stability: role of auto-facilitation. J Neuroendocrinol 13: 158-165, 2001

52. Erkut ZA, Gabreels BA, Eikelenboom J, van Leeuwen FW, Swaab DF: Glucocorticoid treatment is associated with decreased expression of processed AVP but not of proAVP, neurophysin or oxytocin in the human hypothalamus: are PCI and PC2 involved? Neuroendocrinol Lett 23: 33-44,2002

53. Cwikel BJ, Habener JF: Provasopressin-neurophysin II processing is cell-specific in heterologous cell lines expressing a metallothionein-vasopressin fusion gene. J Biol Chem 262: 14235-14240, 1987

54. Andersen MK, Sorensen JB: Development of syndrome of inappropriate secretion of antidiuretic hormone during progression of metastatic breast cancer. Acta Oncol 36: 535-537, 1997

55. Howard AC, Laing RW, Hussain FN: Breast carcinoma presenting with inappropriate ADH secretion. Eur J Cancer 29A: 2339, 1993

56. Gupta A, Sasarula S, Rao PV: The syndrome of inappropriate secretion of antidiuretic hormone in a case of carcinoma of the breast. J Assoc Physicians India 34: 441-442, 1986

57. Du J, Keegan BP, North WG: Key peptide processing enzymes are expressed by breast cancer cells. Cancer Lett 165: 211-218, 2001

58. Seufferlein T, Rozengurt E: Galanin, neurotensin, and phorbol esters rapidly stimulate activation of mitogen-activated protein kinase in small cell lung cancer cells. Cancer Res 56: 5758-5764, 1996

59. Chiu T, Wu SS, Santiskulvong C, Tangkijvanich P, Yee HF Jr., Rozengurt E Vasopressin-mediated mitogenic signaling in intestinal epithelial cells. Am J Physiol Cell Physiol 282: C434-450, 2002

60. Thibonnier M, Conarty DM, Plesnicher CL: Mediators of the mitogenic action of human V(l) vascular vasopressin receptors. Am J Physiol Heart Circ Physiol 279: H2529-2539, 2000

61. Gilad L, Bresler T, Gnainsky J, Smirnoff P, Schwartz B: Regulation of vitamin D receptor expression via estrogen-induced activation of the ERK 1/2 signaling pathway in colon and breast cancer cells. J Endocrinol 185: 577, 2005

62. Lu Y, Zi X, Zhao Y, Pollak M: Overexpression of ErbB2 receptor inhibits IGF-I-induced Shc-MAPK signaling pathway in breast cancer cells. Biochem Biophys Res Commun 313: 709-715, 2004

63. Zivadinovic D, Watson C: Membrane estrogen receptor-alpha levels predict estrogen-induced ERK1/2 activation in MCF-7 cells. Breast Cancer Res 7: R130-R144, 2005

64. Folny V, Raufaste D, Lukovic L, Pouzet B, Rochard P, Pascal M, Serradeil-Le Gal C: Pancreatic vasopressin V1b receptors: characterization in In-R1-G9 cells and localization in human pancreas. Am J Physiol Endocrinol Metab 285: E566-576, 2003

65. Bunn PA, Jr., Dienhart DG, Chan D, Tagawa M, Jewett P: Effects of neuropeptides on human lung and breast cancer cells. J Natl Cancer Inst Monogr : 145-151, 1992 